\title{
'Grave-paved Stars': Comparing the Death of Two Artists in Nineteenth-century Rome
}

\author{
Kiera Lindsey
}

University of Technology, Sydney

\section{ABSTRACT}

Adelaide Ironside (1831-1867) is best known as the first Australian-born artist to train overseas. While her life offers a portal into Republican Sydney, Pre-Raphaelite London and Risorgimento Rome, the nature of her archive also highlights the limits of historical method and the need to employ what Virginia Woolf called 'the biographer's licence' when researching and writing about subjects with problematic sources. In this article, I employ biographical license to contrast the betterknown and better-documented death of the English poet John Keats (1795-1821), with the few records associated with Ironside's death some forty years later, and to speculate about the silences in her sources. There are several factors encouraging this approach. Both artists died in Rome of pulmonary tuberculosis. Both were patients of the famous doctor, Sir James Clark (1788-1870), and both died during winter in the care of the person with whom they are now buried. By situating Ironside within these broader nineteenth-century contexts, my biographical subject evolves from a shadowy historical representative of demographic and an era into a figure who is more flesh and blood than an account focused upon her accomplishments and acquaintances might otherwise allow.

Keywords: tuberculosis, Adelaide Ironside, John Keats, nineteenth-century Rome 


\section{'GRAVE-PAVED STARS': COMPARING THE DEATH OF TWO ARTISTS IN NINETEENTH-CENTURY ROME. ${ }^{1}$}

In the brilliant constellation of lady artists at Rome, there shone no brighter star than Adelaide Ironside, who has just disappeared. I shall never forget when, at the request of Gibson, I paid my first visit to her studio, the impression which she made upon me before I had the privilege of looking at her creations. Full of nervous sensibility, she was the impersonation of genius; her mind was too active for the delicate frame in which it dwelt and it required not the gift of prophecy to see that one possessed of so many endowments would shortly pass away.

'Obituary: Adelaide Ironside', The Athenaeum, 11 May 1867 (624-625).

Adelaide Ironside (1831-1867) is best known as the first Australian-born artist to train overseas. ${ }^{2}$ The granddaughter of a transported forger and Sydney's Chief Gaoler, she was born at a time when the colony was still a penal settlement and came to adulthood during a brief period of radical republicanism. During her decade or so abroad, Ironside associated with numerous 'Eminent Victorians' in Pre-Raphaelite London. She also resided in Rome during the Italian Risorgimento-a period when a host of expatriate female artists were enjoying greater professional and personal freedom than their counterparts at home. While Ironside's life offers a fascinating portal into those pasts, the idiosyncratic nature of her archive draws attention to the challenge of researching and writing about biographical subjects whose historical records are somehow particularly problematic. ${ }^{3}$ Although Ironside's archive is more substantial than that of many nineteenth-century women, her sources nonetheless highlight the limits of historical method and the need for what Virginia Woolf called 'the biographer's licence'. ${ }^{4}$ For while her archive comprises realia (e.g. material objects), artwork, poetry and over 100 letters, only fifteen of these were written by Ironside, ensuring her voice is frequently muted and her perspectives often difficult to determine. ${ }^{5}$

In search of my subject, I trawled the primary and secondary records of Ironside's better-known associates, including Elizabeth Barrett and Robert Browning and John Ruskin. In addition to looking for correspondence from or about her, I have sought clues regarding their relationship with, and attitude to, my subject. When it comes to writing about Ironside's death, her archive is even scantier. There is only one letter written by her while she was dying, three that were written by her mother after her death, and the above obituary, which was first published in the Athenaeum then syndicated to numerous British and colonial papers. ${ }^{6}$ There is also a 
gravestone that was erected in the 1980s. Such circumstances have compelled me to consider whether the archives associated with the death of one person might illuminate another. Or, to be more precise, if the records concerned with the death of the English poet John Keats (1795-1821) can prompt useful speculations and shed some light upon Ironside's death, which was also in Rome, albeit some forty years later.

\section{WAS IT A VISION OR A WAKING DREAM?}

My interest in this approach began with the relatively well-known sketch Joseph Severn made of Keats in Rome in January 1821 (Figure 1), and a

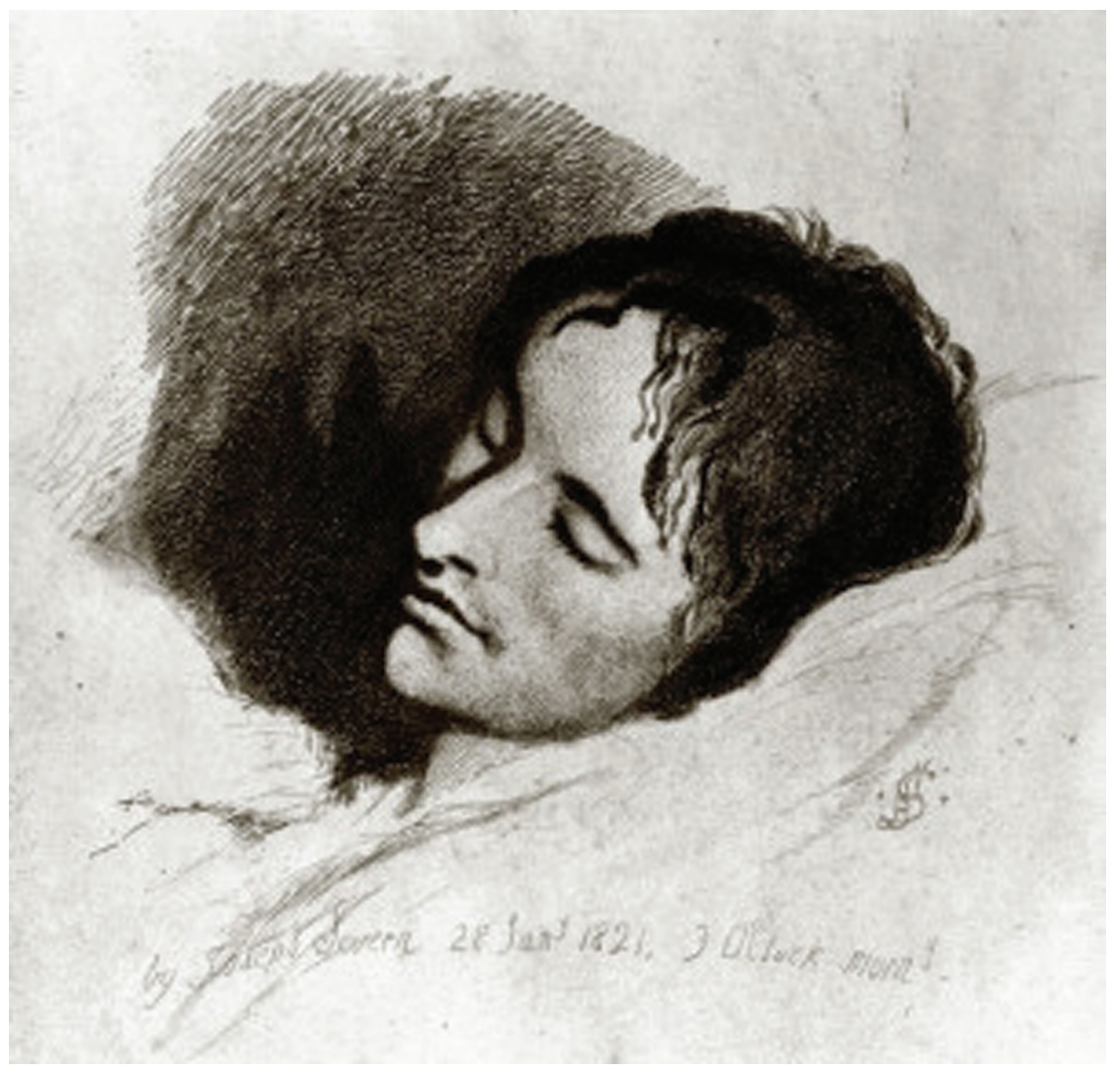

Figure 1 Joseph Severn, '28 Janry 3 o'clock mng. Drawn to keep me awake-a deadly sweat was on him all this night'. 28 January $1821 .{ }^{12}$ 


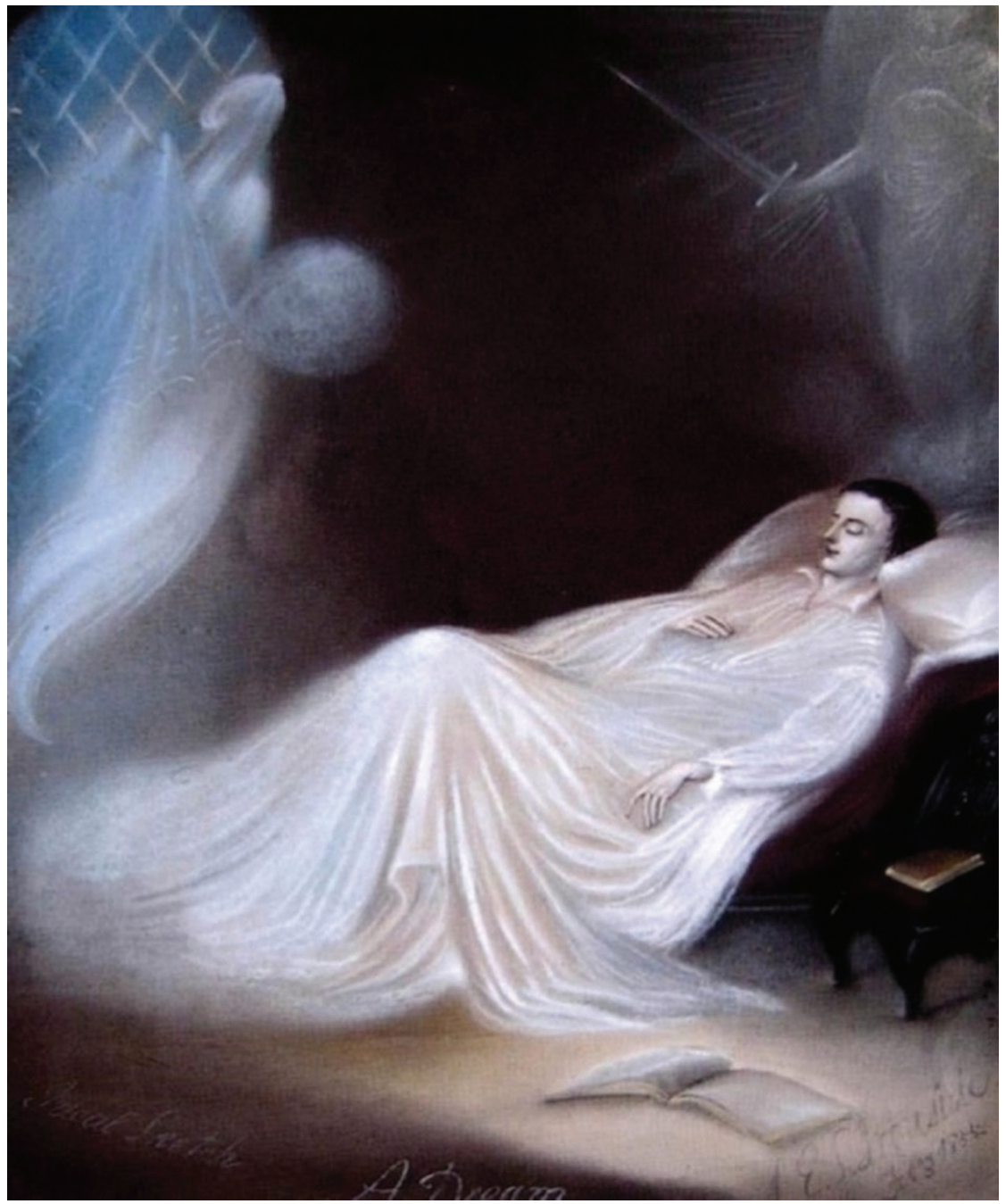

Figure 2 Adelaide Ironside, A Dream, (Ideal Sketch), February 1855, Museum of Tasmania.

chalk work entitled A Dream (Ideal Sketch), completed by Ironside in February 1855 (Figure 2). It was the similar angle of the two reclining figures, each with pallid skin and closed eyes, on the thresholds of asleep/ awake, living/dying, that sparked my interest in the possibility that Keats' better-documented death might provide a way of speculating about the silences in Ironside's sources. ${ }^{7}$ There are several factors encouraging this 
approach. Both artists died in Rome of pulmonary tuberculosis, commonly known as phthisis throughout this period. ${ }^{8}$ Both were patients of the famous doctor Sir James Clark (1788-1870) and both died during winter in the care of the person with whom they are now buried. ${ }^{9}$ Despite dying over forty years apart, both artists also knew many of the same people. Indeed, Keats was nursed by and died in the arms of Joseph Severn, then an aspiring artist but, by the time of Adelaide's death, the British Consul in Rome. ${ }^{10}$ Severn was also an associate of the Ironsides and expressed his sympathy to Adelaide's mother, Martha, when he learned of the artist's death. ${ }^{11}$

However, while Keats is now one of England's most celebrated poets, Ironside is little known, even within Australia. There is only one biography about her and this devotes scant attention to her illness and death. ${ }^{13}$ In contrast, since Richard Monckton Milnes published the first of many biographies in 1848 , Keats has become "the poster child of youthful artists' whose lives were stolen by tuberculosis. ${ }^{14}$ In addition to this, letters from Keats, Severn and James Clark furnish us with intimate details regarding his decline and death. ${ }^{15}$ Here, I refer to these primary sources, as well as those relating to Ironside and her associates and my own recent visits to the places where both artists lived, died and are buried. ${ }^{16}$

Situating Ironside within these comparative contexts has offered new insights into her death and her life. Early in my research, for example, I was struck by the claim made by the author of the Athenaeum obituary, Henry Wreford, regarding Ironside's genius. ${ }^{17}$ These comments did not align with my estimation of her artwork, for, while Ironside was an accomplished draftsperson who chose ambitious subjects and media, her surviving artworks do not display the sort of bold originality typically associated with some of her contemporaries. ${ }^{18}$ It appears that Robert Browning may have shared similar reservations, for in a letter to a mutual friend, he described this obituary as an 'extraordinary book'. ${ }^{19}$ Wreford's claims remained perplexing until I began to place Keats and Ironside within the nineteenth-century 'cult of the invalid'-and a context which Carolyn A. Day recently described as 'consumptive chic'. ${ }^{20}$

These entwined trends emerged in the second half of the eighteenth century and remained influential well into the 1850 s, during a period when tuberculosis was the cause of 25 percent of deaths throughout Europe. $^{21}$ These conditions remained persistent, both Thomas Dormandy and Frank Snowden note, despite the extensive medical attention devoted to the causes and cures of consumption. ${ }^{22}$ As this illness became a source of growing frustration and despair, ideas that helped to alleviate the associated confusion and suffering also became increasingly influential. One particularly popular belief assumed that, as the disease wasted 
the body, it allowed the mind and soul to soar free in ways that imbued the consumptive with a 'quickening of genius' and led to a creative outpouring that served as a divine compensation for their shortened life. ${ }^{23}$ Such ideas also associated the disease with heightened ecstasy and creative sensibility and, as Susan Sontag argues, linked consumption with rich and beautiful elites. ${ }^{24}$ Indeed, there was a time, Snowden recounts, when it was thought impossible for the so-called underclasses to contract what was then believed to be an aristocratic ailment. ${ }^{25}$ Such attitudes also linked phthisis with class and beauty in ways, Day argues, that encouraged women to emulate the gaunt, fragile figure of the consumptive in their comportment, dress and makeup with the hope that they would be admired for 'sensibility, intelligence and refinement'. ${ }^{26}$

Situating Ironside's obituary in these contexts explains why Wreford first determined Ironside's genius from 'her nervous sensibility' and 'delicate frame', well before he 'had the privilege' of 'looking at her creations'. It was, in short, Ironside's disposition-rather than her art-that conformed with elements of consumptive chic and made her, he tellingly states, 'the impersonation (my italics, K.L.) of genius'. This realisation is likely to inform the way I understand not only Ironside's death but also her life, for it suggests there was something performative about the colonial artist that aligned with contemporary ideas of sensibility and convinced others she was especially gifted. ${ }^{27}$ Similar influences may be detected in much of Keats' poetry, particularly Ode to A Nightingale (1819), which suggests that, like many of his age, Keats was also 'half in love with easeful death' in ways that emulated and encouraged elements of this 'cult' and 'chic'. ${ }^{28}$ Throughout this speculative experiment, I quote that poem to evoke these sentiments and contrast them with the actual primary sources associated with his death. As Severn's biographer Sue Brown insists, the sources associated with Keats' death tell a much more 'gruesome' story than the 'eulogistic imagery' in his poetry and later legends suggest. ${ }^{29}$ By focusing upon these grim details, I hope to speculate about what it might have been like for Adelaide Ironside to die from tuberculosis in nineteenth-century Rome-and for her mother, Martha, to care for and then mourn her.

\section{THE WEARINESS, THE FEVER, AND THE FRET}

The story of how Keats first coughed blood a year before travelling to Italy is well known. ${ }^{30}$ Both his training at Guy's Hospital and experience of nursing his brother Tom, who died of consumption in 1818, allowed Keats to correctly diagnose the spots of red on his handkerchief as his 'death-warrant'. ${ }^{31}$ As both Tom and his mother had died of consumption, Keats conformed to the contemporary 'doctrine of essentialism', which 
assumed that familial disposition was a primary cause of the disease. ${ }^{32}$ With his slim build and vivid imagination, friends considered Keats illequipped to manage the excitements and disappointments associated with both the poor reviews his poetry received and his thwarted romance with Fanny Brawne, believing that these circumstances made him particularly vulnerable to 'the greatest killer of the age'. ${ }^{33}$

In September 1820, 25-year-old Keats left England in the company of Severn and with the slim hope a Roman winter might provide the "change of air' believed to revive the consumptive invalid. ${ }^{34}$ Keats carried a vial of laudanum, which he intended to use if, or rather when, his condition became unbearable. During the three-month boat journey, his health continued to deteriorate and by the time he and Severn arrived in Rome, Keats was in a pitiful condition. Dr James Clark found the two men accommodation above Piazza di Spagna. Initially, the Scottish doctor thought Keats' illness was 'seated in the stomach', a 'disease of the heart [...] maybe $[\ldots]$ the lungs' ${ }^{35}$ He recommended horse-riding and exposed his patient to starvation and bleeding. ${ }^{36}$ By mid-December, however, Keats was regularly vomiting 'two cupfuls of blood', sometimes 'five times more'. ${ }^{37}$ This Severn considered 'the lesser evil when compared with his Stomach' which was now 'so distended' that Keats was 'perpetually hungry' but 'unable to take nourishment'. By Christmas Eve, the mood descended further into 'despair and wretchedness' as all three men accepted that Keats was consumptive, and fatally so. ${ }^{38}$ By early January 1821, Clark was visiting four to five times a day, and was increasingly distressed to find "poor Keats[...] deplorable state [...] his stomach ruined [...] digestive organs deranged and lungs [...] diseased'.$^{39}$ Keats suspected the same, and as 'the entire loss of bodily strength and appearance' broke 'his heart and spirit', the young English poet began to express feelings of 'malevolence, suspicion $[\ldots]$ persecution $[\ldots]$ even murder' ${ }^{40}$

\section{'BEING TOO HAPPY IN THY HAPPINESS'}

When Adelaide Ironside arrived in Rome with her mother in early 1856, she was the same age as Keats had been in 1820. Such was her brimming optimism, however, that the moment she disembarked she knelt down and 'kissed the dust of Italy' ${ }^{41}$ Ironside's mentor, the irascible colonial politician and Presbyterian minister, Dr John Dunmore Lang, had given her a letter of introduction to Clark, who was now in London and serving as Queen Victoria's chief physician. ${ }^{42}$ Clark was still well-connected in Italy and secured Ironside's entrée into Rome's expatriate community, who were impressed by her ambition and ability, although some did raise eyebrows over what Browning described as Adelaide's 'wild and enthusiastic ways' ${ }^{43}$ 
For the following decade, the Ironsides made Rome their home, only returning to England so that Adelaide could exhibit at the 1862 London International Exhibition and then train with Ruskin in 1865. During this time Ironside studied fresco in Perugia and Florence, was active in the expatriate community and earnt a living as a portraitist. However, just before leaving for London in 1862, she wrote to a friend describing symptoms that appear compatible with pulmonary consumption:

I have had a very bad cold indeed, [...] I quite lost my voice for a month [...] can only speak in a whisper [...] if I speak out the pain in my chest is very great[.] ${ }^{44}$

There is nothing to indicate Ironside consulted a doctor at this time. Instead, she appears to have taken her treatment into her own hands, experimenting with homeopathic treatments: 'colourifics, mustard poultices', even peppermint tea. ${ }^{45}$ In the same letter she also mentions how the Welsh sculptor and doyen of the Roman art scene, John Gibson, had mentioned her 'quite blooming' complexion-one of several features, Sontag and Snowden both note, that was particularly admired in women during this period precisely because it was associated with consumption. ${ }^{46}$

It is impossible to confirm whether Ironside contracted tuberculosis in Rome in the early 1860s, in London during her fleeting visit in late 1855 or perhaps earlier, while still in Sydney. Just as conjecture continues regarding the cause of Keats' illness, Ironside's cannot be definitively diagnosed. ${ }^{47}$ Her mother believed Adelaide's decline had been exacerbated by over-exertion and the disappointing response her work received at the 1862 Exhibition. ${ }^{48}$ It was also suggested that her decline had been hastened by knowledge that her colonial colleague-Daniel Deniehy-who may have been her unrequited love, had died suddenly in $1865 .{ }^{49}$ Certainly, the sources from this period contain growing expressions of concern regarding her health and increasingly erratic behaviour. ${ }^{50}$ By early 1866, Ironside's physical appearance was causing alarm among her colonial friends, the Wentworths, who were then living in London. Writing to her sister, who was still living in Sydney, Laura Wentworth noted of their guest, 'little Miss Ironside':

The poor little thing has a most dreadful cough and is so thin when undressed it is wonderful she can get about as she does[.] ${ }^{51}$

Throughout 1866 the now-retired Clark frequently urged Adelaide 'quietly and slowly' back to Rome. ${ }^{52}$ The Ironsides attempted to do precisely this but were twice thwarted by her fragile condition. ${ }^{53}$ By October, however, mother 
and daughter were finally back in their apartment in Via Quattro Fontane where, like Keats, Adelaide now prepared to face a difficult winter.

\section{'WHERE YOUTH GROWS PALE AND SPECTRE-THIN'}

During the last months of his life Keats was tormented, Severn recalled, by his thwarted talent and frustrated romance, bitterly grieving a life of disappointment and failure. ${ }^{54}$ One day, he told Severn he was so impatient with his 'posthumous existence' he wanted 'the laudanum vial' Severn had confiscated. When Severn refused, Keats threw two full coffee cups at him. ${ }^{55}$ Keats and Severn had never been close, but once entrusted with his care Severn surprised everyone with his devotion. ${ }^{56} \mathrm{He}$ assumed all the 'menial offices', making beds, building fires, sweeping floors, even managing the finances and doctor appointments. He also distracted Keats from his suffering by playing the piano and reading aloud, typically spending day and night at his friend's bed, 'cooling' his 'burning forehead' and humouring him in all 'his wanderings'. ${ }^{57}$

Severn also had to contend with a landlady who suspected Keats was contagious. Severn had been told that the authorities would demand the destruction of not only the infected patient's personal possessions but everything, 'even the papers on the walls'. ${ }^{58}$ His anxieties increased when he learned he was also responsible for the costs of 'new windows, new doors $[\ldots]$ even a new floor'. ${ }^{59}$ For months, the three played cat and mouse as visitors came and went, the weather got colder and unpaid bills piled up. Throughout this period, despite Severn's and Clark's efforts, Keats continued to change 'very, very, very much', until over the new year 'the slender hope of recovery' finally dissolved. ${ }^{60}$ But then, suddenly, on 11 January, Severn wrote to Fanny Brawne's mother confident he would bring his friend back to England, which Keats had previously expressed 'a dread of never seeing' again. ${ }^{61}$

\section{'O FOR A BEAKER FULL OF THE WARM SOUTH'}

I know little of what happened in the Ironsides' apartment during the winter of 1866 until 10 January-almost to the day Severn wrote to Mrs Brawne-when 35-year-old Ironside penned what is now her last remaining letter. In this she reminded her old pastor, Dr Lang, that it was 'exactly eleven years to the day' since the Ironsides had first arrived in Rome and that she had spent the winter 'wrapped in flannels and in blankets', with 'all the strength taken by the cold of Europe'. ${ }^{62}$ Like Keats pining for 
England, the Ironsides were thinking of home and planning their return, for in this letter she describes how mother and daughter were longing for 'the quiet life and genial climate' of their 'native land',-_hoping that this might allow her to 'regain a portion of life and health'. Nonetheless, like Keats, Ironside was also clearly preparing for other eventualities:

-if He who willeth all things aright has deemed otherwise (for the chances are uneven and uncertain), my health being so extremely delicate that every fresh attack endangers my life I send out to my country [...] those paintings which I have kept to show my countrymen. [...] This last affliction has drained me much from the world and I have learned in calm submission to 'kiss the rod' and be content that it is not worse. ${ }^{63}$

\section{'FADE, FAR AWAY, DISSOLVE AND QUITE FORGET'}

But it did get worse, and as Adelaide had little more than three months to live, we might assume that she now began to experience similar suffering to Keats-fevers with chattering teeth, night sweats and hallucinations. Indeed, it is tempting to wonder if, like Keats, she also 'slept in restless fits', only to wake suddenly with 'an expression of horror and doubt' in her eyes as she searched the dark for her mother's familiar face. ${ }^{64}$ Did her 'expectoration' turn 'a fawn colour, sometimes streaked with blood' and her stomach also become horribly distended? As the letters of the period describe Adelaide as already unhealthily thin, we might imagine that during those final weeks her appearance became increasingly distressing.

Drawing upon Severn's sources, we might also wonder if, like Keats, Ironside spent hours staring at the ceiling pattern, struggling to summons the strength to cough up the blood-stained sputum 'gurgling' in her throat. ${ }^{65}$ Unlike Keats, who had a view of the piazza, Ironside looked out onto the street and at that time Via Quattro Fontane was already a major thoroughfare. After more than a decade in Rome, the traffic was probably of little interest. As Ironside's apartment had previously functioned as her studio, it was likely she turned inward, perhaps to her paintings and her past.

As Keats began to decline, Severn stayed close by, listening to his memories of 'everything that was dear and delightful, even to the minutiae.'.6 We might wonder if Martha also encouraged Adelaide to recall her past triumphs or perhaps simpler details from her bucolic childhood growing up on Sydney's then remote North Shore ${ }^{67}$ Or did Martha likewise distract herself by sweeping floors and making beds? Over the last decade, the Ironsides' financial circumstances had been dependent upon Adelaide's earnings. Did her mother suffer similar anxieties to Severn regarding the 
doctors' bills? Both women were avid readers and Ironside's letters contain references to Dante, Wordsworth, Byron, Shelley and Longfellow. We might speculate that Martha read such works to Adelaide. Or perhaps mother and daughter preferred 'the infantile productions' of Adelaide's early poetry ${ }^{68}$

It was early spring when Adelaide's health took its final turn. From the letters her mother wrote to Dr Lang afterwards, we know something of 'the deep affliction' Martha experienced as she watched her 'very adored child sinking day by day, weaker and weaker'. ${ }^{69}$ 'How', she confided to Lang, 'in the last two days' Adelaide's noises 'became like a young child's'. Throughout it all, however, Martha insisted, Adelaide kept 'her precious mind perfect to the last'. So much so that when Adelaide finally died she did so, Martha believed, 'full of hope in Christ [...] rejoicing in the hope of glory'. ${ }^{70}$

\section{'BUT TO THINK IS TO BE FULL OF SORROW'}

This was not to be Keats' end. Even though he 'felt the horrible want of faith, some hope, something to rest on', he would not allow Severn to read the Bible aloud. ${ }^{71}$ Other books were, however, permitted, and Keats listened to these with 'dreadful earnestness' ${ }^{72}$ With 'no religion, no philosophy to support him', Severn prayed 'some angel of goodness' might comfort his friend's 'dark wilderness' ${ }^{73}$ But instead, it was Keats who cared for Severn. Recognising that his friend had been brought low by successive night vigils, Keats arranged for a nurse. Severn used this respite to visit the non-Catholic Cemetery, returning to delight Keats with descriptions of the goats and sheep that grazed about Giaus Cestius' pyramid tomb. ${ }^{74}$ Keats was so pleased he began to contemplate how the daisies scattered about the cemetery would soon be growing over his grave, and days later he instructed Severn about his end. There would be no false hope, no grandiose recognition, and absolutely no visual mementos; on his tombstone. He wanted only that 'his name was writ on water'. ${ }^{75}$

In contrast, we know from a scrawled note in the Ironside archive that, a few months before she died, the Ironsides had a photographic portrait taken of Adelaide for a carte de visite. ${ }^{76}$ As this is the only confirmed photograph we have of her, it now serves as a memento mori of Adelaide's final moments and is, therefore, the focus of the Creative Matters piece accompanying this article. ${ }^{77}$

\section{'FORLORN! THE VERY WORD IS LIKE A BELL!'}

In mid-February, Keats began to prepare his friend for the end. 'I pity you, poor Severn', he said one afternoon, 'what trouble you have got into 
for me-now you must be firm for it will not last long'. ${ }^{78}$ Later Severn heard Keats mumble, 'O! I can feel the cold earth upon me-the daisies growing over me'. ${ }^{79}$ The moment seemed close but then, next morning, Keats awoke and his mood turned bitter once again. There was another agonising day and night, relieved by the nurse who let Severn sleep until the following afternoon when she noticed a change and called him to Keats who was now glistening with sweat. 'Severn-S-lift me up for I am dying', he slurred, '-I shall die easy-don't be frightened-thank God it has come'. He was so feverish Severn's breath on his cheek felt 'like ice'. 'Don't breathe on me', Keats said. And so Severn sat quietly, holding his friend in his arms, listening as the breathing became softer. Several hours passed before Severn saw, then touched the still cold hands and knew. ${ }^{80}$

Next, plaster casts were made of Keats' face, hands and feet. ${ }^{81}$ Clark conducted an autopsy and found the lungs among the worst he had seen thus far in his career. In contrast, the only information we have of Ironside's autopsy, if indeed there was one, are the words inscribed on her carte de visite, dated 7 May 1867. These indicate that, 24 days after her death, Dr Markham determined Adelaide Eliza Ironside had 'died of natural causes resulting from an illness of the chest'. ${ }^{82}$

\section{'IN ANCIENT DAYS BY EMPEROR AND CLOWN'}

In one of his final letters, Keats expresses a desire to be buried 'near [...] Fanny Brawne'. ${ }^{83}$ As he prepared to die, however, Keats spoke more of a quiet grave and being buried somewhere he might be forgot. In fact, his funeral procession began in the morning of the most riotous day of the Carnivale, when the streets were packed with crowds dressed in gaudy costumes. Severn had suffered a breakdown and was in the care of Clark's wife, while the Scottish doctor arranged the funeral. To avoid a backlash from local inhabitants, who occasionally reacted violently to Protestant ceremonies, the party took the back streets. According to Severn's account, there were only nine mourners and he recalled being 'the only personal friend' at the grave, where Clark honoured Keats' request to have daisy-strewn clods of earth heaped upon his coffin. ${ }^{84}$

In Ironside's archive, there is an undated letter from John Gibson's partner, Penry Williams. ${ }^{85}$ In 1866, Gibson had died and been buried in the same cemetery and Martha must have been considering interring Adelaide there, for this letter details the associated costs. Shortly afterwards, however, Martha wrote to Lang outlining her intention to return to Sydney with her daughter's 'immortal remains'. ${ }^{86}$ She would do so via London, she told him, for she first wished to secure Adelaide's legacy and pay for the passage home. This she would achieve by obtaining the 
outstanding subscriptions required to publish her daughter's celebrated watercolours of forty-three Australian Wildflowers as a book. ${ }^{87}$

Shortly after Keats's funeral, Severn returned to Piazza di Spagna where he discovered that the landlady had let in the 'Italian brutes' hired to eliminate the threat of contagion by destroying everything associated with a dead consumptive. These men had already dragged Keats' clothes and bedding onto the street below and set them alight. When Severn arrived and discovered they were ripping off the wallpaper he flew into a rage that was so fierce he managed to rescue Keats' pocket watch and ring before Clark arrived and took the distressed young man away. ${ }^{88}$

I am yet to determine the official policy in Rome 1867, and so know little of what Martha faced during the hours and days after her daughter's death. I do not know if 'brutes' came to burn her daughter's clothes and bedding, although I can speculate that, by then, the great number of British visitors convalescing in Rome each winter may have resulted in the formalisation of practices that accommodated rather than deterred what had become a lucrative form of 'health tourism, ${ }^{89}$ I also suspect that, had Martha decided to bury her daughter in the non-Catholic cemetery, the procession would have faced less hostility than in early 1821, when mourners carried Keats's coffin through the backstreet to avoid confrontation. During Gibson's funeral in 1866, for example, authorities enlisted guards not to protect the party but to honour a man who had lived in Italy for over 40 years.$^{90}$ By the time of her death, Ironside had resided in Rome for over a decade; during that time, she had been patronised by Pope Pius IX and befriended both local and expatriate artists. It is therefore likely that had she been buried locally her funeral would have been better attended than Keats'.

As the weeks went by, Severn gradually recovered his 'shattered health' and began to focus upon his art and the community that would become his home. In contrast, the autopsy date suggests it took 55-year-old Martha three weeks to recover sufficiently to determine her next steps. It may have been then that she realised she would need the medical report provided by Dr Markham if she was to return to Sydney via London with her daughter's remains.

\section{'THE SAD HEART OF RUTH, WHEN SICK FOR HOME'}

By the time Martha made the sombre journey from Rome to London, improvements to the roads, coupled with the advent of the railway, had dramatically reduced this trip from the three-month sea journey Keats had taken in 1820. When, for example, Sir Charles Eastlake-another associate of the Ironsides-died in Pisa in late 1865, his widow organised the return of his remains to London in a journey that took less than a week. ${ }^{91}$ We 
might imagine Martha and her grim wake travelling out of Rome, equipped with the carte de visite autopsy and official papers that had been signed by Severn in his capacity as the British Consul to ensure she suffered minimal interference at the various borders she would need to cross. Letters must have been exchanged en route, for by the time she arrived in London it was agreed that Martha would stay with the wealthy silk merchant, William Leaf. It was also decided that Adelaide's remains would be stored-temporarily-in the Leaf family vault within the catacombs of West Norwood cemetery. $^{92}$

\section{'I CANNOT SEE WHAT FLOWERS ARE AT MY FEET'}

Letters in the family papers of the Ironsides' colonial friends suggest that within a year Martha was also 'consumptive'-exhausted, some suggested, from the effort of attempting to secure the outstanding subscriptions for the Australian Wildflowers book. ${ }^{93}$ During those months, Martha obtained numerous commitments for this collection, including the Prince of Wales, but before she could secure the final few the publisher was declared bankrupt. ${ }^{94}$ That was winter 1868. By March 1869, Martha Ironside was dead. Colonial friends rushed to Leaf's home where they found her laid out on the bed her daughter had often slept in, surrounded by white roses just as Adelaide had been, according to the Athenaeum obituary. ${ }^{95}$ Days later, Leaf organised for the two women to be buried together. There were no records of the funeral or what, if anything, was organised for their tombstone. The only record is in the Pall Mall Gazette: 'IRONSIDE Martha R-relict of Mr J of Sydney N.S.W., at Streatham, aged 55, March $14{ }^{\prime}{ }^{96}$ A stark contrast to the lengthy columns devoted to her daughter's death.

\section{'FADE AWAY INTO THE FOREST DIM'}

In the 1980s, Ironside's first biographer collaborated with Ironside descendants to erect a stone on the plot where the cemetery records indicate both women were interred. ${ }^{97}$ I visited this in 2018 - or rather the area around it, for by then the surrounding gravestones and trees were so obscured by ivy and weeds it was impossible to know where the two women lay. This wilderness was markedly different to the well-trimmed violets planted about the grave Keats and Severn now share in Rome's non-Catholic Cemetery. When I visited there in 2019, I was struck by the possibility that Keats may have preferred the 'verdurous glooms' of the Ironsides' grave to his own highly manicured memorial. ${ }^{98}$ 


\section{CONCLUSION: 'TO THY HIGH REQUIEM'}

This article is part of a project concerned with not only writing Adelaide Ironside's biography, but also experimenting with ways of writing the lives of those for whom we now have little more than archival traces. By comparing her death in Rome with that of Keats some forty years earlier, I have experimented with two loosely connected case studies in ways that are fruitful for my speculative processes but raise questions about historical and biographical method. I now wish to outline my tentative findings before considering if this exercise has allowed me to negotiate the tensions between historical integrity and imagination in ways that have been productive for my larger biographical project concerned with Adelaide Ironside.

Although we cannot be certain about the cause of their illness and deaths, according to contemporary understandings, both Keats and Ironside were particularly susceptible to phthisis. When Keats came to Rome the expatriate community was small, medical services improvised, and James Clark a relatively young doctor. Keats' medical experience was such that he understood there was little hope of recovery. Indeed, he carried a laudanum vial to ensure he could 'die easy'. ${ }^{99}$ Although Ironside was the same age as Keats when she first arrived in Rome in 1856, she was an ambitious artist, enthralled with Italy and intent upon 'a life of aspiration'. ${ }^{100}$ By then, a veritable industry existed in Rome for phthisic patients. This, coupled with a culture of 'consumptive chic', influenced the way fashionable men and women thought about art, illness and one another. Like Keats, Ironside was slim, imaginative and intense, and contemporaries appear to have associated this with a certain sensibility that led them to believe she was a genius. While the term has lost some of its historical resonance, this discussion of consumptive chic suggests it could refer to a host of personal qualities as much as professional output, and that it was also gendered in ways that valued frailty and delicacy in women as much as, if not more than, their actual artistic productions. Such qualities were certainly identified and admired in Ironside, and help to explain the claims made in the Athenaeum's obituary.

Although Keats and Ironside shared the same physician, by the time the Australian painter called upon Clark's medical expertise, he was a royal physician and one of the leading authorities on consumption. Much had changed since Clark had bled and starved Keats, and yet, by the time Ironside developed a painful chest cough, sore throat and 'blooming' complexion, the medical fraternity was yet to determine its causes and cures. Even though Keats had a degree of medical knowledge, he not only 
accepted Clark's initial diagnosis but also submitted to treatments that may have hastened his decline. In contrast, while Ironside took advice from the Queen's favourite doctor, she also experimented with homeopathic remedies and consulted other doctors. Such differences may be partially explained by the forty years separating the two illnesses. Nonetheless, Ironside's refusal to accept medical advice passively, even from the Queen's physician, suggests a certain independence of character which I have certainly detected elsewhere in her sources.

By the time she returned to Rome in late 1866, Ironside, like Keats, was probably aware that she would die in the Eternal City. Both artists spent their last winter longing for home, but, whilst the English poet wished only to have his name 'writ on water', Adelaide wanted to be remembered. Where Keats explicitly refused any visual mementoes, mother and daughter arranged for a photograph to be taken and made plans for Adelaide's works to be sent to Australia. Together, these factors suggest that, in addition to gender, heritage and age, expectation is crucial to understanding Ironside's life and death.

When she died in 1867, Ironside was a 35-year-old colonial woman who had depicted herself in prose and painting as a 'pilgrim of art'. ${ }^{101}$ As a young woman, she had been encouraged by Sydney's small intellectual community to leave that 'remote colony' and had done so, intent upon winning acclaim from 'the distinguished authorities and first judges of art and artists in Europe' so that she might also 'elevate her sex and hoist the colours of her country' abroad. ${ }^{102}$ Although Ironside had not been as successful as some of her English and American female contemporaries, she had nonetheless exceeded the expectations of her colonial counterparts and would thereafter be remembered as 'the first Australian-born artist' to train overseas. ${ }^{103}$ In so doing, Ironside had poured forth her 'soul abroad' and achieved her artistic ambitions in ways 26-year-old Keats had not. ${ }^{104}$ No wonder, then, that in contrast to Keats' bitter final days, on Ironside's deathbed, she was able to say 'many beautiful things'. ${ }^{105}$ According to contemporary expectations of what was possible for a woman, let alone a colonial woman, Ironside had lived in a way that ensured her star had shone brightly within the "brilliant constellation of lady artists at Rome' ${ }^{106}$ And, ironically perhaps, by dying of consumption, she could also join the 'grave-paved stars' of artists, like Keats, whose talent had been tragically cut short.

\section{'AND LEAVE THE WORLD UNSEEN'}

By situating Ironside within the medical, social and cultural milieu of her age, I have had to think carefully about her body before, during and 
after her death. I have used the raw details offered by Keats, Severn and Clark to bring her physicality and fragility into immediate focus. In the process, my subject has ceased to be simply a historical representative of an era or demographic, or even a portal into a particular past. Instead, by meditating about her death, I have been drawn to carefully reconsider Ironside's embodied life-how she was wracked by dry coughing and excruciating chest pain, how her swollen hands made it impossible to pick up a paint brush. ${ }^{107}$ Far from the romantic figure in the Athenaeum's obituary, I have contended with her distended stomach and diarrhoea. In the process, she has become more human than an account focused upon her art, achievements and acquaintances might allow.

While both Keats and Ironside romanticised death according to the fashion of their age, it was, in fact, Severn and Martha Ironside who managed its mundane realities and painful legacies. Reading Severn's letters provide intimate insights into what it was like to care for, suffer with and be left to manage the legacy of a loved one. While Martha's slim letters offer only glimpses into this experience, Severn's correspondence details the drudgery, despair and demands of the deathbed in ways that remind us how such pressures could 'shatter' the spirits of the carer. ${ }^{108}$

Such observations remind me that biography is never simply the story of an individual, nor an account of an era, but an organic meshing that takes into consideration the unique entanglement of intensities and intimacies which shape both. As death frequently involves such heightened elements, it can offer the biographer a potent lens through which to explore their subject's life. But to do so, especially when writing about individuals whose historical sources are scanty, it can be necessary to speculate in ways that challenge the limits and conventions of historical method, even if such speculations are informed by historical context, as mine have been here. ${ }^{109}$ This, I think, is what American historian Nell Irvin Painter means when she speaks of the need to be resourceful when writing the lives of 'Unusual Suspects'. ${ }^{110}$ If, she insists, we are to ensure we do not 'cede' history to the 'Usual Suspects' - that is, those with the economics, education and influence to leave 'the usual sources for the usual kinds of biographies'-we must construct 'new biographical approaches'. This article and the Creative Matters that accompanies it are offered in precisely that spirit.

\section{ACKNOWLEDGMENTS}

This research is conducted as part of an Australian Research Council (ARC) Discovery Early Career Research Award (DECRA) I am 
conducting at the University of Technology Sydney (UTS). Early discussions with Dr Kees Windland gave this paper frisson and impetus. I would like to thank Professor Frank Snowden from Yale University for sharing the pre-publication pages of his forthcoming book, Epidemics and Society, and commenting upon a draft of this article. I would also like to thank the American Academy of Rome for assisting me with my research. This work has benefited from my father's medical knowledge and attention to expression, as well as suggestions offered by Brian Marshall and Dr Jane Wildgoose. The generous support of these institutions and individuals is greatly appreciated.

\section{WORKS CITED}

\section{Primary Sources}

Clark, James. The Sanative Influence of Climate: With an Account of the Best Places of Resort for Invalids in England, the South of Europe. London: John Murray, 1841.

Ironside, Adelaide. The Marriage at Cana of Galilee. Art Gallery of NSW, 1861, reworked 1863. Ironside, Adelaide. A Dream, (Ideal Sketch). Museum of Tasmania, February 1855.

'Ironside, Martha R — relict of Mr J of Sydney N.S.W.' Pall Mall Gazette, 20 March 1869.

'Miss Ironside.' Empire, 28 April 1856 (5).

'Obituary: Adelaide Ironside.' The Athenaeum, 11 May 1867 (624-625).

Pemell, Amelia. 'Correction: To the Editors of the Herald.' Sydney Morning Herald, 5 July $1921(10)$.

SAG Manuscript Collection 4/12973.

Scott, Grant F., ed. Selected Letters of John Keats. Harvard: Harvard University Press, 2005.

Severn, Joseph. '28 Janry 3 o'clock mng. Drawn to keep me awake-a deadly sweat was on him all this night.'28 January 1821.

SLNSW Blaxland Family Papers, MLMSS 9704.

SLNSW John Dunmore Lang Papers, Vol. 9: ML A2229.

SLNSW Macarthur papers, 34, A 2930.

SLNSW Wentworth Family Papers, ML A868.

SLNSW, Adelaide Eliza Scott Ironside Family Papers, 1854-1868, MSS 272/1.

West Norwood Cemetery, 'J. C. Day to Poulton', 27 September 1984, JCD/MRL/673.

West Norwood Cemetery and Crematorium, Superintendent Register to Mrs Vialls, 9 August 1983, Ref: SBJ/ES/1836.

\section{Secondary Sources}

Agnew, R. A. L. 'Clark, Sir James, First Baronet (1788-1870).' Oxford Dictionary of National Biography, May 2009, https://www.oxforddnb.com/view/10.1093/ ref:odnb/9780198614128.001.0001/odnb-9780198614128-e-5463, doi: https://doi. org/10.1093/ref:odnb/5463. Date accessed: 26 August 2019.

Avery-Quash, Susan and Julie Sheldon. Art for the Nation: the Eastlakes and the Victorian Art World. Yale: Yale University Press, 2011.

Booth, Sharron, 'Venturing into Silences: The Silence of Water (novel) Convicts, Women and Western Australian Stories', (PhD., Edith Cowan University, 2020).

Brown, Charles Armitage. Life of John Keats. Oxford: Oxford University Press, 1937. 
Brown, Sue. Joseph Severn, A Life: The Rewards of Friendship. Oxford: Oxford University Press, 2009.

Cherry, Deborah. Beyond the Frame: Feminism and Visual Culture in Britain 1850-1900. London: Routledge, 2000.

Coverley, M. Psychogeography. Harpenden, England: Pocket Essentials, 2006.

Davis, Natalie Zemon. The Return of Martin Guerre. MA: Harvard University Press, 1983.

Davis, Natalie Zemon. 'On the Lame.' American Historical Review 99:3 (June 1988).

Davis, Natalie Zemon. 'Narrative as Knowing: Stories and the Hunger to Know.' Yale Journal of Criticism 5:2 (January 1992).

Day, Carolyn A. Consumptive Chic: A History of Beauty, Fashion and Disease. London: Bloomsbury, 2017.

De Almeida, Hermoine. Romantic Medicine. New York: Oxford University Press, 1991.

Dormandy, Thomas. The White Death: A History of Tuberculosis. London: Hambledon Press, 1999.

Gilchrist, Archibald. John Dunmore Lang: Australia's Pioneer Republican. Melbourne: New Melbourne Press, 1999.

Hoolihan, Christopher. 'Health and Travel in Nineteenth-Century Rome.' Journal of the History of Medicine and Allied Sciences 44:4 (October 1989) 462-485.

Jordens, Ann-Mari. The Stenhouse Circle: Literary Life in mid-Nineteenth Century Sydney. Melbourne: University of Melbourne, 2015.

Kaloustian, David. 'Severn, Joseph (1793-1879), Painter.' Oxford Dictionary of National Biography, January 2008, https://www.oxforddnb.com/view/10.1093/ ref:odnb/9780198614128.001.0001/odnb-9780198614128-e-25132. Date accessed: 26 August 2019.

Kelley, Philip and Ronald Hudson (eds.). The Brownings' Correspondence, an online edition. https://www.browningscorrespondence.com. Date accessed: 12 December 2016.

Lindsey, Kiera. "Deliberate Freedom": Using Speculation and Imagination in Historical Biography.' In: Kate Douglas, Donna Lee Brien and Kylie Cardell (eds.), TEXT Special Issue 50: Life Writing in Troubled Times, October 2018, 1-16.

Martin, Eliza. The Life E Speeches of Daniel Henry Deniehy. Melbourne: George Robertson, 1884.

McAleer, Edward C. (ed.). Dearest Isa: Robert Browning's Letters to Isabella Blagden. Austin: University of Texas Press, 1951.

McIntire, C.T. England Against the Papacy 1858-1861: Tories, Liberals and the Overthrow of Papal Temporal Power during the Italian Risorgimento. Cambridge University Press, 1983.

Miles, Richard Monckton. The Life and Letters of John Keats. London: Edward Moxon \& Co, 1848.

Newland, Christina. 'The Prettiest Way to Die: Consumption Chic and the 19th-Century Cult of the Invalid.' Literary Hub, 3 October 2017, https://lithub.com/the-prettiest-way-todie/. Date accessed: 14 February 2019.

Painter, Nell Irvin. 'Sojourner Truth in Life and memory: Writing the Biography of an American Exotic.' Gender EO History 2:1 (Spring 1990) 14.

Pesman, Ros. 'In Search of Professional Identity: Adelaide Ironside and Italy.' Women's Writing 10:2 (2003) 2307-2327.

Poulton, Jill. Adelaide Ironside: The Pilgrim of Art. Sydney: Hale \& Iremonger, 1987.

Roe, Nicholas. John Keats and the Medical Imagination. London: Palgrave Macmillan, 2017.

Scott, Grant F. (ed.). Selected Letters of John Keats. Harvard: Harvard University Press, 2005.

Smith, Hillas. 'The Strange Case of Mr Keats's Tuberculosis.' Clinical Infectious Diseases 38:7 (April 2004) 991-993.

Snowden, Frank. 'Doctrine of Essentialism.' In: 'Tuberculosis (1): The Era of Consumption.' Yale Open lectures, Epidemics in Western Society Since 1600 (HIST 234), 18, 17 March 2011, https://www.youtube.com/watch?v=-73rQw31X_g. Date accessed: 29 May 2019. 
Snowden, Frank. Epidemics and Society: From the Black Death to the Present. New Haven: Yale University Press, 2019.

Sontag, Susan. Illness as Metaphor: Aids and its Metaphors. London: Penguin Books, 1990.

Stacey, Michelle. 'Writ in Water": The Enduring Mystery of Keats's Last Words.' The Paris Review, 23 February 2016, https://www.theparisreview.org/blog/2016/02/23/writ-inwater/. Date accessed: 29 August 2019.

Stanley-Price, Nicholas. The Non-Catholic Cemetery in Rome: Its History, its People and its Survival for 300 Years. Rome: Non-Catholic Cemetery, 2014.

Teale, Ruth. 'Ironside, Adelaide Eliza (1831-1867).' Australian Dictionary of Biography, 1972 , National Centre of Biography, Australian National University, http://adb.anu.edu.au/ biography/ironside-adelaide-eliza-3838/text6095. Date accessed: 26 August 2019.

Whitfield, George. Beloved Sir James: The life of Sir James Clark, Bart, Physician to Queen Victoria, 1788-1870. Unpublished gift to Birmingham University YA, 2001.

Woolf, Virginia. 'The new biography.' Granite and Rainbow: Essays. London: Hogarth, 1927.

\section{ABOUT THE AUTHOR}

Dr. Kiera Lindsey is an award-winning historian and Senior Research Fellow at the University of Technology Sydney, where she is conducting an Australian Research Council grant on speculative biography and historical craft. Lindsey has published national and international academic book chapters and journal articles on nineteenth-century history, historical craft and biography. In 2016 she published her first speculative biography, The Convict's Daughter, and will publish her second on the colonial artist, Adelaide Ironside in 2021, along with a new co-edited collection on Speculative Biography with Routledge. Kiera has over twenty years of university curriculum development and delivery across in-class, online and blended platforms, been a consultant and on-camera historian on television and national radio and is currently an executive member of the History Council of New South Wales. E-mail: Kiera.lindsey@ uts.edu.au.

\section{NOTES}

1 The phrase 'Grave-paved stars' is taken from Thomas Lovell Beddoes, Death's Jest-Book, Act II, as quoted in Dormandy, Thomas, 1999 (85).

2 Poulton, Jill, 1987; Teale, Ruth, 1972; Pesman, Ros, 2003. While each of these works contributes to our understanding of Ironside, they focus primarily upon her contribution to art and literature and colonial society, more generally. The objective of this article is to see if it is possible to draw upon context and acquire what Natalie Zemon Davis termed 'informed imagination' to develop a deeper understanding of Ironside's embodied experience as a nineteenth-century woman.

3 Ironside's archive is held in private collections, the State Library of NSW (SLNSW) and Society of Australian Genealogists (SAG). Her art is in the National Gallery of Australia, as well as numerous State and regional galleries and private collections. 
4 Woolf, Virginia, 1927 (155).

5 Lindsey, Kiera, 2018.

6 This obituary was published in the London Athenaeum and then syndicated to twenty UK papers and seven in Australia.

7 Ironside also presented herself to Italy's expatriate community as a medium. See Poulton, Jill, 1987 (57); Kelley, Philip and Ronald Hudson (eds.), Vol. 24 (140-142).

8 Dormandy, Thomas, 1999, discusses these various terms in his Introduction and Chapter 1.

9 Whitfield, George, 2001, also Agnew, R. A. L., 2009.

10 Brown, Sue, 2009; Kaloustian, David, 2008.

11 Severn to Martha Ironside, April 1867, SLNSW Ironside Family Papers, MSS 272/1/371. Both artists also knew the sculptor and British expatriate William Ewing, whom Severn sent out for ices to soothe Keats' throat. Brown, Sue, 2009 (106).

12 Brown, Sue, 2009.

13 Poulton, Jill, 1987 (Chapter 13).

14 Newland, Christina, 2017; Biographies on Keats are too numerous to list within the strictures of word count, but commence with Miles, Richard Monckton, 1848, and include Nicholas Roe's relevant scholarship, specifically John Keats and the Medical Imagination.

15 These have been repeatedly published since Monckton-Milne's 1848 account. I refer throughout to Scott, Grant F. (ed.), 2005.

16 I am indebted to Sharron Booth who describes M Coverely's practice of 'pyschogeography' which involves retracing the steps of a biographical subject to stimulate an 'interplay between location and imagination'. I used this technique to retrace Ironside's life and glean much about her actual life in Rome, including the view of her apartment on Via Quattro Fontane. See Booth, Sharron, 'Venturing into Silences: The Silence of Water (novel) Convicts, Women and Western Australian Stories', (PhD., Edith Cowan University, 2020); Coverley, M. (2006). Psychogeography. Harpenden, England: Pocket Essentials.

17 Henry Wreford was the Times' correspondent in Italy; see McIntire, C.T., 1983 (44-45); Poulton, Jill, 1987 (106).

18 For example, Welsh sculptor, John Gibson (1790-1866), claimed that Ironside 'would smash' William Holman Hunt 'out of the park' at the 1862 London Exhibition, SLNSW Macarthur papers 34, A 2930 (151-156). Comparison of the work these artists showed at the Exhibition, Ironside's The Marriage at Cana of Galilee and Hunt's Christ in the Temple of his Father, highlights the originality of Hunt's work.

19 Letter 100, Browning to Blagden, 19 June 1867 in McAleer, Edward C. (ed.), 1951.

20 Day, Carolyn A., 2017.

21 Idem (2).

22 Dormandy, Thomas, 1999; Snowden, Frank, 2019 (282-292).

23 Snowden, Frank, 2019 (282-291); Dormandy, Thomas, 1999 (85-99).

24 Sontag, Susan, 1990 (12-37).

25 Snowden, Frank, 2019 (289-294).

26 Idem (282); Day, Carolyn A., 2017 (3).

27 See for example, Roger Therry to William Macarthur, 16 March 1862, SLNSW, Macarthur papers 34, A 2930, 151-156; Charles Eastlake to Ironside, 23 May 1865, SAG Manuscript Collection 4/12973.

28 Keats, John, Ode to a Nightingale, 1819.

29 See Day, Carolyn A., 2017 (50); Brown, Sue, 2009 (95-96).

30 For example: Smith, Hillas, 2004; De Almeida, Hermoine, 1991; Roe, Nicholas (ed.), 2017.

31 On 3 February 1820, Keats coughed blood onto his bedsheets, and, according to his friend, Charles Armitage Brown, exclaimed, 'I know the colour of that blood; it is 
arterial blood; I cannot be deceived in that colour; that blood is my death-warrant; I must die'. See Letter to Fanny Keats, 6 February 1820, footnote 2, in Scott, Grant F. (ed.), 2005 (412); also Brown, Charles Armitage, 1937 (80).

32 Snowden, Frank, 2011.

33 Idem (285), where Snowden quotes Samuel Cartwright; Dormandy, Thomas, 1999 (4149 , xiv) cites medical theories and also describes tuberculosis as 'the greatest killer of the age'. For references re: the causes of Keats's illness and death see Severn to Taylor, 24 December 1820; Severn to Haslam, 15 January 1821; Severn to Taylor 25-26 January 1821 in Scott, Grant F. (ed.), 2005; For discussion re: the epitaphs friends produced re: these causes, see Stacey, Michelle, 2016.

34 Snowden, Frank, 2011 (292-294). Clark published extensively on this topic, including, The Sanative influence of climate: with an account of the best places of resort for invalids in England, see Clark, James, 1841.

35 Ibidem; Keats to Charles Brown, 30 November 1820, in Scott, Grant F. (ed.), 2005 (485).

36 Ibidem.

37 Severn to Charles Brown, 14 December 1820, in Scott, Grant F. (ed.), 2005 (486).

38 Severn to John Taylor, 24 December 1820, in Scott, Grant F. (ed.), 2005 (488).

39 James Clark to unknown, 3 January 1821, in Scott, Grant F. (ed.), 2005 (503).

40 Severn to John Taylor, 24 December 1820, in Scott, Grant F. (ed.), 2005 (488).

41 Ironside to Lang, 24 October 1859, SLNSW John Dunmore Lang Papers 9: ML A2229/203.

42 'Miss Ironside', Empire, 28 April 1856 (5); Gilchrist, Archibald, 1999.

43 Browning to Hosmer, 27 March 1856, Kelley, Philip and Ronald Hudson (eds.), (161-165).

44 Ironside to Caroline Clark, 7 February 1862, SLNSW, Adelaide Eliza Scott Ironside Family Papers, 1854-1868, MSS 272/188/97.

45 Ibidem.

46 Snowden, Frank, 2011 (283); Day, Carolyn A. 2017 (48, 85, 95); Sontag, Susan, 1990 (29).

47 Smith, Hillas, 2004.

48 With American sculptor Harriet Hosmer, Ironside was a 'particular pet' of Gibson's. All three showed work at the 1862 Exhibition and Gibson told Ironside she would 'smash Holman Hunt' and his new work 'out of the park'. SLNSW Macarthur papers 34, A 2930 (151-156). Numerous colonists flocked to London for this event, and Adelaide hoped to secure wealthy patrons, but despite some nibbles all deals fell through. In contrast, following excellent reviews, Hosmer attracted several new patrons. This may have stung Ironside, as Hosmer actively encouraged a spirit of competition with Ironside once referring to her as her 'fair foe'. Adelaide Eliza Scott Ironside Family Papers, 1854-1868, MSS 272/188/111 \&112.

49 Martin, Eliza, 1884 (5).

50 Ruskin to Ironside, 22 July 1865, SLNSW, Adelaide Eliza Scott Ironside Family Papers, 1854 1868 , MSS 272/1/195 (c).

51 Laura to Timmy, 5 January 1866, SLNSW Wentworth Family Papers, ML A868.

52 Clark to Ironside, 30 April, 8 and 10 May 1865 and 17, 28 May, 9, 17 and 29 August 1866, SLNSW, Adelaide Eliza Scott Ironside Family Papers, 1854-1868, MSS 272/1.

53 William Leaf to Ironside, 11 September 1866, SAG Manuscript Collection 4/12973.

54 Keats, 30 November 1820, in Scott, Grant F. (ed.), 2005 (485).

55 Brown, Sue, 2009 (101).

56 Between his first letter in November 1820 and his second in January 1821 Clark's opinion of Severn improved: Scott, Grant F. (ed.), 2005 (484 and 497).

57 Severn, 14 December 1820, in Scott, Grant F. (ed.), 2005 (487-494).

58 Severn to Taylor, 6 March 1821, in Scott, Grant F. (ed.), 2005 (510).

59 Ibidem. 
60 Ibidem.

61 Severn to Mrs Brawne, 11 January 1821, in Scott, Grant F. (ed.), 2005 (498-500).

62 Ironside to Lang, 10 January 1867, SLNSW John Dunmore Lang Papers Vol. 9: ML A2229/249.

63 Ibidem.

64 Severn to Haslam, 15 January 1821, in Scott, Grant F. (ed.), 2005 (501-503).

65 Severn to John Taylor, 26 January 1821, in Scott, Grant F. (ed.), 2005 (504-506).

66 Severn, 26 January 1821, in Scott, Grant F. (ed.), 2005 (504-506).

67 Letters to Lang, August 1862, SLNSW John Dunmore Lang Papers Vol. 9: ML A2229/214.

68 'Obituary: Adelaide Ironside', The Athenaeum, 11 May 1867 (624-625).

69 Martha Ironside to Lang, 18 June 1867, SLNSW John Dunmore Lang Papers Vol. 9: ML A2229/251.

70 Ibidem.

71 Severn 24 December 1820, in Scott, Grant F. (ed.), 2005 (490-494).

72 Ibidem.

73 Severn, 15 January 1821, in Scott, Grant F. (ed.), 2005 (501-503).

74 Brown, Sue, 2009 (106).

75 Ibidem.

76 'Photograph of Cousin Addie, taken shortly before she died', Adelaide Eliza Scott Ironside Family Papers, 1854-1868, MSS 272/1/371.

77 See (in publication) 'Creative Matters: "A Short time before her Death", European Journal of Life Writing: Special Issue.

78 Brown, Sue, 2009 (108-109).

79 Ibidem.

80 Ibidem.

81 Ibidem.; Severn to Taylor, 6 March 1821, in Scott, Grant F. (ed.), 2005 (510-511).

82 SLNSW Adelaide Eliza Scott Ironside Family Papers, 1854-1868, MSS 272.2/101.

83 Keats to Brown, 1-2 November 1820, in Scott, Grant F. (ed.), 2005 (481-483).

84 Brown, Sue, 2009 (110).

85 Penry Williams to Martha Ironside, 22 April 1867, SAG Manuscript Collection 4/12973.

86 Martha Ironside to Lang, 30 June 1868, SLNSW John Dunmore Lang Papers Vol. 9: ML A2229/255.

87 Correspondence from publisher John D. Day, 18 August 1866, SAG Manuscript Collection 4/12973; Ironside to Louisa Blaxland, 23 August 1866, SLNSW Blaxland Family Papers MLMSS 9704; Blaxland to Ironside, SLNSW Adelaide Eliza Scott Ironside Family Papers, 1854-1868, MSS 272/1-4.

88 Severn to Taylor, 6 March 1821, in Scott, Grant F. (ed.), 2005 (510-511).

89 Hoolihan, Christopher, 1989 (468). When Keats and Severn came to Rome, there were fewer than 2,000 British people living in Italy, of whom the majority resided in Rome. By the 1850 s, ideas about the city's beneficial climate and conditions were so popular that each winter, about thirty-five thousand British visitors made the city home. Many, but far from all of these would have been health tourists.

90 Stanley-Price, Nicholas, 2014 (52).

91 Avery-Quash, Susan and Julie Sheldon, 2011 (182-185). Eastlake was first interred in the non-Catholic Cemetery in Florence. His manservant oversaw his employer's disinterment and escorted his remains across Europe to London so he could be buried at Kensal Green.

92 Superintendent Register to Mrs Vialls, 9 August 1983, West Norwood Cemetery and Crematorium, Ref: SBJ/ES/1836 states Adelaide Ironside was removed from the catacombs and buried with her mother on 18 March 1869 in Grave No 11836 Square 77. 
93 Laura to Timmy, 25 March 1869, SLNSW Wentworth Family Papers, ML A868.

94 Martha to Herbert Fisher, 22 August 1867, SLNSW Adelaide Eliza Scott Ironside Family Papers, 1854-1868, MSS 272/1/357.

95 Laura to Timmy, 25 March 1869, SLNSW Wentworth Family Papers, ML A868.

96 Pall Mall Gazette, 20 March 1869.

97 J. C. Day to Poulton, West Norwood Cemetery, 27 September 1984, JCD/MRL/673.

98 Keats, John, 1819.

99 Brown, Sue, 2009 (108-109).

100 Cherry, Deborah, 2000 (41).

101 Ironside entitled one of her paintings 'The Pilgrim of Art' and in a letter to Lang referred to her own 'pilgrimage of art ...'; Poulton used the term as the title of her biography. Ironside to Lang, 20 February 1863, SLSNW John Dunmore Lang Papers Vol. 9: ML A2229/252-4.

102 Jordens, Ann-Mari, 2015.

103 In footnote 45, I describe Ironside's relationship with the American sculptor Harriet Hosmer, who was another close associate living in Rome, who received better reviews and commissions than Ironside. Cherry, Deborah, 2000, describes the manysuccessful British female artists who were Ironside's contemporaries during this period. Ironside's colonial friends certainly believed she should be remembered in this way, indeed, more than fifty yearslater, herfriend,Amelia Pemellwrote to the colonial pressinsistingupon thisfact, see Pemmell, Amelia, 1921 (10).

104 Keats, John, 1819.

105 Martha Ironside to Lang, 18 June 1867, SLNSW John Dunmore Lang Papers Vol. 9: ML A2229/251.

106 Athenaeum obituary.

107 Ibidem: during the final two years Ironside was too ill to paint.

108 'Shattered' is used by both: Severn to Taylor, 6 March 1821 in Scott, Grant F. (ed.), 2005, and Martha Ironside to Lang, 18 June 1867.

109 Natalie Zemon Davis used the term 'informed imagination' to describe the methods she used in her celebrated but contentious The Return of Martin Guerre, see Davis, Natalie Zemon, 1983; Davis, Natalie Zemon, 1988; Davis, Natalie Zemon, 1992.

110 Painter, Nell Irvin, 1990 (14). 